Meta

Journal des traducteurs

Translators' Journal

\title{
Naturalness in the Spanish Dubbing Language: a Case of Not-so-close Friends
}

\section{Pablo Romero Fresco}

Volume 54, numéro 1, janvier 2009

URI : https://id.erudit.org/iderudit/029793ar

DOI : https://doi.org/10.7202/029793ar

Aller au sommaire du numéro

\section{Éditeur(s)}

Les Presses de l'Université de Montréal

ISSN

0026-0452 (imprimé)

1492-1421 (numérique)

Découvrir la revue

Citer cet article

Fresco, P. R. (2009). Naturalness in the Spanish Dubbing Language: a Case of Not-so-close Friends. Meta, 54(1), 49-72. https://doi.org/10.7202/029793ar
Résumé de l'article

Le présent article examine l'idiomaticité de la langue espagnole utilisée dans le doublage. Il montre qu'il est préférable d'analyser la langue de doublage en la comparant au registre qu'elle imite, du moment que ses caractéristiques particulières sont prises en compte. L'étude est divisée en deux parties. La première donne une description des caractéristiques qui rendent le dialogue doublé différent du dialogue réel. Cette description est axée sur les traits spécifiques du texte de départ. La seconde est une analyse comparée du dialogue doublé et du dialogue réel. Dans cette partie, un corpus de conversations spontanées sert de point de référence pour un dialogue considéré comme naturel. Les principales stratégies utilisées dans la conversation courante déterminent les unités linguistiques à analyser : les marqueurs de degré et autres marqueurs du discours. Les caractéristiques de non-idiomaticité identifiées sont l'utilisation d'anglicismes, particulièrement sur le plan pragmatique, et un changement de ton, susceptible de causer une variation dans la relation entre les participants dans le texte résultant du doublage. Enfin, la notion de « suspension d'incrédulité linguistique » est proposée comme explication possible de la perpétuation du manque de naturel dans la langue utilisée pour le doublage.
Ce document est protégé par la loi sur le droit d'auteur. L’utilisation des services d’Érudit (y compris la reproduction) est assujettie à sa politique d'utilisation que vous pouvez consulter en ligne.

https://apropos.erudit.org/fr/usagers/politique-dutilisation/ 


\title{
Naturalness in the Spanish Dubbing Language: a Case of Not-so-close Friends ${ }^{1}$
}

\author{
PABLO ROMERO FRESCO \\ Roehampton University ${ }^{2}$, London, UK \\ p.romero-fresco@roehampton.ac.uk
}

\begin{abstract}
RÉSUMÉ
Le présent article examine l'idiomaticité de la langue espagnole utilisée dans le doublage. II montre qu'il est préférable d'analyser la langue de doublage en la comparant au registre qu'elle imite, du moment que ses caractéristiques particulières sont prises en compte. L'étude est divisée en deux parties. La première donne une description des caractéristiques qui rendent le dialogue doublé différent du dialogue réel. Cette description est axée sur les traits spécifiques du texte de départ. La seconde est une analyse comparée du dialogue doublé et du dialogue réel. Dans cette partie, un corpus de conversations spontanées sert de point de référence pour un dialogue considéré comme naturel. Les principales stratégies utilisées dans la conversation courante déterminent les unités linguistiques à analyser: les marqueurs de degré et autres marqueurs du discours. Les caractéristiques de non-idiomaticité identifiées sont l'utilisation d'anglicismes, particulièrement sur le plan pragmatique, et un changement de ton, susceptible de causer une variation dans la relation entre les participants dans le texte résultant du doublage. Enfin, la notion de «suspension d'incrédulité linguistique» est proposée comme explication possible de la perpétuation du manque de naturel dans la langue utilisée pour le doublage.
\end{abstract}

\begin{abstract}
The present article examines the Spanish dubbing language from the point of view of its naturalness. The premise is that dubbing language is best analyzed by comparing it to the register it imitates, as long as its peculiar features are taken into consideration. This study is divided into two parts: firstly, a description of the features that make dubbing dialogue different from real dialogue, focusing on those arising from the source text; secondly, a comparative analysis of dubbed and real dialogue. In the latter, a corpus of spontaneous conversations will be used as a yardstick for natural dialogue and the main strategies used in colloquial conversation will provide the linguistic units to be analyzed: intensifiers and discourse markers. The main unidiomatic features detected are the use of anglicisms, especially at the pragmatic level, and a certain shift in tone that may cause a variation in the relation among the participants in the dubbed text. Finally, the notion of suspension of linguistic disbelief is put forward as a possible explanation for the perpetuation of unnatural features in dubbing language.
\end{abstract}

\section{MOTS-CLÉS/KEYWORDS}

discourse markers, dubbese, intensifiers, naturalness, Spanish dubbing language, suspension of linguistic disbelief

\section{Introduction}

In his reflection on new potential avenues of research in audiovisual translation (AVT), the Spanish scholar Jose María Bravo (2005) complains about the lack of studies on the language used in translated films, especially in films and other audiovisual texts dubbed from English into Spanish. According to Bravo, there is great 
potential in the study of dubbed dialogues, especially because of their contradictory nature - they are meant to sound natural and spontaneous and yet have been written beforehand, so they are often artificial and very elaborated. Bravo (2005: 132; my translation) concludes that he is not aware "of the existence of any rigorous research analyzing the features of film language and drawing the corresponding conclusions from a translational viewpoint."

Indeed, other than the odd description of dubbing language as "deflated," "stilted" or "unnatural" (Whitman-Linsen 1991:120, 274), only a few authors like Herbst (1994) in German and Chiaro (2005) and Pavesi et al. (2006) in Italian have actually dealt with the "register of dubbing" (Marzà et al. 2006), sometimes referred to as dubbese (Myers 1973; Heiss 2004). The same holds true for Spain, where Chaume's study (2004a) on the prefabricated orality of texts dubbed into Spanish is probably the most relevant work to date. Unfortunately, most studies on the subject seem to leave the same questions unanswered: how can the naturalness of a dubbed text be assessed? Having used a well-built parallel corpus made up of a source text (ST) and a target text (TT), who is to decide which TT units are natural and which ones are not? Does the native condition of the scholar suffice to make such a statement or do we need a yardstick against which the naturalness of the dubbed text can be measured?

This article attempts to answer some of these questions by looking at the Spanish dubbing language from the point of view of its naturalness. The premise is that dubbing language is best analyzed by comparing it to the register it imitates (colloquial register, in the case of the corpus under study), as long as its peculiar features are taken into consideration. This is not to say that dubbing language, or indeed film language, is always an imitation of real-life conversation. There is no hiding from the fact that fictional dialogue is highly scripted, thus presenting a "contrived realism" (Pérez-González 2007:6) that is sometimes no more than "a canonical approximation of spontaneous talk in interaction" (Boxer 2002:18). However, more often than not, this dialogue will try to evoke reality. This is regarded by Pérez-González as "real realism" (2007:7) and is achieved through natural and spontaneous-sounding dialogue that facilitates the identification of the viewers with a film. The success of this realism is proved by the fact that fictional dialogue is often found to mirror real dialogue (Pratt 1997, Rose 2001). The corpus under scrutiny here, the American sitcom Friends, has been identified as a case in point (Tagliamonte and Roberts 2005). In this sense, some scholars go as far as to propose fictional dialogue as a useful tool for the study of real conversation (Murphy 1977, Tannen and Lakoff 1994). In this article, the similarity between real and fictional dialogue serves as a launch pad for a different approach -the use of real dialogue to investigate fictional, or rather dubbed, dialogue. As pointed out by Baumgarten (2005:78), this is a very useful way of looking at dubbing language, especially given that the production of realistic and natural dialogues is both a "cornerstone of dubbing" (Chaume 2007) and one of the most important recommendations in style sheets for dubbing translators (Televisió de Catalunya 1997).

This study is divided into two parts: (1) a description of the features that make dubbing dialogue different from real dialogue, focusing on those arising from the ST, and (2) a comparative analysis of dubbed and real dialogue. In the latter, a corpus of spontaneous conversations will be used as a yardstick for natural dialogue and the 
main strategies used in colloquial conversation will provide the linguistic units to be analyzed - intensifiers and discourse markers.

\section{Pinning down a vague concept}

Choosing the concept of naturalness as a starting point to study the so-called dubbese, in this case the Spanish dubbese, brings about a number of advantages and disadvantages. The main advantage is that the notion of naturalness is wide enough to account for the different features of dubbing language. All too often, the presence of calques and anglicisms is posited as the main (sometimes even the only) reason why dubbing language may sound stilted or contrived (Gómez Capuz 2001). As a result, some authors (Duro Moreno 2001) restrict their analysis of dubbing language to the influence of the source language (SL). Whereas this may well be appropriate in many cases, other factors also seem to contribute to the wooden style sometimes attributed to dubbing language (Romero Fresco 2008). As will be described here, the notion of naturalness in dubbing should be able to account for these factors.

However, the obvious drawback of working with naturalness is that, by casting the net too wide, we are left with a very vague concept; one that is especially difficult to pin down and dangerously prone to trigger impressionistic observations. Perhaps this is the reason why, despite being a critical issue in dubbing, naturalness has traditionally taken a back seat in scholarly research to the analysis of the different constraints (mainly synchrony) of this type of translation. In any case, one of the objectives of this paper is to show that the notion of naturalness in dubbing can actually be applied in a more objective and less vague way.

First of all, naturalness is used in this article as a synonym of idiomaticity, which is thus not regarded as "given to or marked by the use of idioms" (Onions 1964:952), but as "[use of language that] sounds natural to native speakers of that language" (Sinclair 1995:833). In this sense, idiomaticity is often defined as "completely natural and correct in grammar and style" (Walter 2005:324). Although apparently similar to the previous one, this last definition strikes a different note and brings about an important problem. It equates grammatical correctness with naturalness/idiomaticity but, is complete grammatical correctness the only requirement for an expression to be idiomatic/natural?

Warren (2004) rightly considers this view to be too broad to account for the features of idiomaticity. Definitions of this type focus on what is grammatically possible (or correct) rather than on what is conventional, constituting for Warren (2004:5) "a serious sin of omission among theoretical linguists, which only now is beginning to be rectified." Accordingly, idiomaticity/naturalness is regarded here as what is conventional, frequent, among the many options that are possible in a given situation. Drawing on Pawley and Syder (1983), Warren (2004:1) defines idiomaticity as the "nativelike selection of expression" that involves "knowing which particular combinations are conventional in a language community although other combinations are conceivable" (2004:5). However, Warren's definition seems to lack some kind of reference to the context, given that what is natural in a given situation may differ greatly from what is natural in another. Therefore, naturalness/idiomaticity is described in this article as nativelike selection of expression in a given context. Admittedly, this definition is still indeterminate and far from being specific enough 
to be used objectively. However, the last addition referring to a given context paves the way to a more empirical approach, as will be shown below.

\section{Corpora and methodology}

The relevance of the notion of frequency in this article highlights the importance of the different corpora under study:

a) a parallel corpus consisting of transcripts (therefore post-synchronized) of the American TV series Friends (ST) and their dubbed versions in Spanish (TT): 300,000 words approximately. Friends is one of the most successful series of all time and, in many ways, the quintessential sitcom, featuring realistic dialogues that are designed to sound believable and spontaneous (Nye et al. 2005).

b) a comparable corpus made up of the Spanish dubbed version of Friends (TT) and the Spanish sitcom Siete vidas (SV): 300,000 words approximately. Siete Vidas is the first and so far most successful sitcom produced in Spain and is clearly inspired by Friends in terms of characters, plots, settings etc. (Huerta 2005).

c) the spontaneous speech section of the Spanish corpus CREA, elaborated by the Real Academia Española, featuring approximately 12 million words.

The idea is to assess the naturalness of the TT (a dubbed version of the ST produced in Spain) by comparing it to the language used in SV (originally in Spanish but not spontaneous) and to the language used in CREA (spontaneous) ${ }^{3}$. This approach begs a number of questions: are the audiovisual texts chosen for this study comparable? If so, what units are to be analyzed? And, most importantly, can dubbed dialogue and real dialogue be compared on equal terms?

As far as the last question is concerned, it goes without saying that fictional dialogue differs from spontaneous dialogue, and so does its idiomaticity/naturalness (or lack of it). The different "possible" options among which a natural, idiomatic phrase is chosen in real speech are considerably narrowed down in fictional dialogue, which is highly conditioned by specific narrative requirements and even AVT constraints in the case of a dubbed text. Bakhtin (1986) describes fictional dialogue as a secondary speech genre (prefabricated orality in Chaume [2004a] as applied to AVT), which derives some of its features from the primary speech genre of daily conversation and others from the text or context in which it occurs (Remael 2003). Drawing on Bakhtin's description, this article adopts a two-fold approach. Firstly, it describes some textual and contextual characteristics of fictional dialogue, particularly focusing on those factors in the ST that may have an effect on the idiomaticity of the dubbed text and that determine what is possible in a given situation. Taking into account these factors, attention will subsequently be drawn to a comparison between the dubbed text and the primary speech genre of daily conversation, which will determine what is conventional, idiomatic in a given situation.

\section{Determining factors in the achievement of a natural dubbed text}

The following factors are bound to have an impact on the naturalness of the dubbed text:

- The ST: some textual and contextual considerations. - the prefabricated orality of the ST 
- The TT

- AVT issues (constraints, the prefabricated orality of the TT...)

Needless to say, due consideration has been given to AVT issues such as constraints and the prefabricated orality of the TT, especially in the qualitative study of the corpus, for which Chaume's model (2004a) for the analysis of audiovisual texts has been applied. However, as indicated above, this article focuses mainly on factors related to the elaboration of the ST. These factors seem to have been consistently overlooked in AVT (Gambier 2006), even though they can have a considerable impact on the dubbed text.

\subsection{The ST}

From the point of view of its mode, the ST can be described as "written to be spoken as if not written" (Gregory and Carroll 1978:42). This definition, which also applies to the TT, is especially relevant to this study, as it hints at what could be a potential lack of idiomaticity of fictional dialogue -the text is meant to be spoken as if it had not been written, that is, naturally. The presence, then, of written features in the script may make it unidiomatic. However, although Gregory and Carroll's definition is undoubtedly very useful and often quoted in studies on this subject, it somehow falls short of accounting for the full complexity of fictional dialogue.

Consider this complexity in the case of a situation comedy. Unlike in spontaneous, real-life dialogue, the several possible choices available in a given situation, or in a conversation, are limited in a sitcom by many and very specific constraints. In the case of Friends, for instance, some of these constraints are the themes and the plots (friendship is the main theme in Friends but then every episode contains three different plots), the characters (six main characters, all of whom have to appear and play an important part in every episode), the settings (except for two or three minutes in every episode, most scenes are shot in the same familiar settings or "centres of action" [Mayhew Archer 2005]), the duration (21-22 minutes with a break of 7-8 minutes before which a cliff-hanger is often needed) etc. All these factors affect the dialogue and its idiomaticity. Other general features of fictional dialogue to be taken into account from this point of view are its polyfunctionality (Pfister 2001), that is, the fact that it is addressed to both the characters (diegetic level) and the audience (extradiegetic level), and especially what is often considered as "the single most distinguishing feature of dramatic dialogue" (Baumgarten 2005:86), the fact that "every linguistic unit - including phenomena of dysfluency and error - is there for a reason. Every linguistic unit fulfills a function for the overall communicative goal of the dramatic dialogue." Finally, also important is the overriding comic purpose of the ST, especially considering that $80 \%$ of the scenes end up on punch line or a comic climax stressed by the sound of canned laughter. All these factors determine to a great extent what can and cannot be said, leaving little room for manoeuvre and constraining the dialogue in a sort of straightjacket. And yet the conversations are supposed to sound idiomatic and spontaneous (Berger 1990). Bearing those two essential aspects in mind, fictional dialogue could thus be defined as straightjacketed dialogue that is intended to sound natural.

A brief account of the elaboration process of an episode will suffice to demonstrate to what extent the dialogue is determined by this straightjacket. First of all, 
with regard to the authorship, an average episode of a series like Friends has between ten and fifteen authors, who write and rewrite the scripts over and over again, but who are not always writers. The director and the actors also tend to play an important part in revising the scripts, especially on the set. This multiple authorship is likely to have an effect on the spontaneity of the dialogues, but even more important is how carefully the latter are elaborated. In sitcoms, spontaneity is meticulously planned over almost two months: the dialogues are planned for half a month, then they are written over ten to fifteen days and finally acted and produced over the next fifteen to twenty days (Kelly 2003). Seeing as the dialogues are not written until they have been planned for half a month, they could be regarded as the icing on the cake or, more accurately, the tip of a carefully built iceberg.

TABLE 1

Example of straightjacket in sitcom (episode 7 season 4)

Plot A: Joey... (7 minutes - 6 scenes)

Plot B: Chandler.... (7 minutes -6 scenes)

Plot C: Ross plays his music to his friends, who tell him that it is great. However, they think

it is dreadful and only Phoebe likes it. Finally Ross gives up so as not to upstage

Phoebe.(7 minutes - 5 scenes)

1st Act: Set-up - the problem is established (3 minutes)

Scene 1

Scene 2: Ross plays the keyboards for his friends. They tell him it is great. Ross leaves the room to go and get something in his flat. They all comment on how bad it is except for Phoebe, who loves it.

2nd Act: Development - the conflict is developed (2 minutes)

Scene 3

Scene 4

2nd Act: Resolution - the conflict is resolved (2 minutes)

Scene 5

Table 1 presents the straightjacket of a specific scene in episode 7 , season 4 , before the scriptwriters elaborate what are meant to be natural-sounding dialogues. As is usually the case, this episode has three plots (A, B and C), of all which are developed over three acts, with a similar duration and a similar number of scenes. The scene under scrutiny here is scene 2, which closes the first act in plot C. Each act in plot C is supposed to last between 2 and 3 minutes and to contain 1 or 2 scenes, which therefore have an average duration of 1-2 minutes. Scene 2 lasts one and a half minutes. In this period of time, the scene must show Ross playing the keyboards, Ross leaving the room to go to his flat, his friends' positive reaction while he is there and his friends' honest opinion once he is gone. Therefore, no more than 15-20 seconds are left for the very last part (in bold), in which Monica, Rachel, Chandler and Phoebe give their opinion about Ross' playing, thus moving the plot forward for the next scene in the next act. Besides, according to the way the plot has been laid out, Monica, Rachel and Chandler have to give a very negative opinion about Ross' music, whereas Phoebe is supposed to be very enthusiastic about it. Finally, yet another constraint is that every line uttered by a character must be true to his/her personality as well as usually comic enough to trigger canned laughter, as is the case in $80 \%$ of the scenes in the corpus. 
This straightjacket, in which scriptwriters are supposed to introduce naturalsounding dialogue, must be taken into consideration when assessing the naturalness of either the ST or the TT, as it makes fictional dialogue different (though still comparable) from real-life dialogue. Needless to say, if this were a real life situation, Ross' friends comments about his playing would be determined by the situation and by what has been said before, among other aspects, but there would be a considerable number of possible choices among which they could find an idiomatic way to express themselves. In the example above, however, the many constraints reduce the number of possible choices, thus leaving less room for idiomatic manoeuvre.

TABLE 2

\section{Comments on Ross's music}

- Monica: Oh, God bless my dad sound proofing the basement!
- Rachel: Oh, I can't believe I ever let him touch me with those fingers.
- Phoebe: What are you guys talking about, I loved it! It was soo moving.
Oh, plus it's just, it's so different from the stuff you usually hear.
- Chandler: You mean music?

Table 2 shows the dialogue introduced in the above straightjacket. In 15 seconds, the four characters move the plot forward as planned by expressing their views, which are not only comic but also true to their personalities. Monica and Rachel utter comic remarks based on their conditions as Ross' sister and ex-girlfriend respectively. Phoebe proves to be once again out of sync with the rest, which will trigger both laughter and the development and conclusion of this plot, as seen in Table 1. Finally, Chandler provides the necessary comic ending for the scene triggering canned laughter with a true-to-form ironic remark.

\subsection{A proposal for new definitions of fictional dialogue}

Having shown both the plan (table 1) and the dialogue introduced (table 2), as well as the extent to which the former determines the latter, it becomes clearer that Gregory and Carroll's definition ("written to be spoken as if not written" [1978:42]) does not quite do full justice to the complexity of fictional dialogue. It starts from the tip of the iceberg (written), thus disregarding the iceberg itself (the planning phase), without which the tip cannot be fully understood. Apart from the first definition of sitcom dialogue proposed in this article (straightjacketed dialogue that is intended to sound natural), fictional dialogue is therefore regarded here, from the point of view of its mode, as a type of dialogue that is planned to be written and to eventually be acted as if not written.

This second definition takes into consideration all the different parts that may (and probably will) have an effect on the idiomaticity of the ST and the TT. Its importance lies in the realisation that naturalness could be affected not only in the change from written to oral, as mentioned in the case of Gregory and Carroll's definition, but anywhere in the three-stage journey from mind (when it's planned), through paper (when it's written) to mouth (when it's acted). Excess luggage from the planned or the written phase in the final oral/acted stage could cause naturalness to fall by the wayside. 
Also relevant to the idea of naturalness in fictional dialogue are Halliday's views on speech and writing. According to Halliday (1985:81), "written language represents phenomena as products," and "spoken language represents phenomena as processes." Whereas writing is done, finished, like and object, speech is being done, it is happening. In a sitcom, the script has been written and is therefore an object. It has already happened. However, it is shown to the viewers as speech, as something that is happening, as a process. It is a "been there, done that" passed off as a "being there, doing that." Most importantly, Halliday considers that when we speak, we do things. To some extent, we drive the plot of the story we are going through. In the case of fictional dialogue, although it may seem that the characters are also determining the plot as they speak, the plot has been determined beforehand. They are not driving the plot but are driven by the plot. Therefore, a key aspect of fictional dialogue, of the prefabricated orality and its naturalness is its condition as a plot-driven object passed off as a plot-driving process.

$\begin{array}{ll}\begin{array}{l}\text { Proposed definitions of fictional dialogue: } \\ \text { straightjacketed dialogue }\end{array} & \begin{array}{l}\text { that is intended to sound natural } \\ \text { planned to be written }\end{array} \\ \begin{array}{l}\text { and to eventually be acted as if not written } \\ \text { plot-driven object }\end{array} & \begin{array}{l}\text { passed off as a "being there, doing that" } \\ \text { passed off as a plot-driving process }\end{array}\end{array}$

It should be noted that all four definitions of fictional dialogue proposed here follow the same "agenda-plus-naturalness" pattern. On the left side, the conventions, the constraints, the need to plan and write, to lay out the plots and meet certain requirements. On the right side, the end result, the need to show just the tip of the iceberg as if there were no iceberg; in other words, the need to achieve, or fake, naturalness and spontaneity. However, these definitions of fictional dialogue leave some questions unanswered: does this mean that fictional dialogue is always natural/idiomatic? If not, what makes it natural or unnatural?

First of all, if we agree that fictional dialogue is natural dialogue with an agenda, or straightjacketed dialogue that intends to sound natural, it follows that the agenda is the main obstacle for it to sound natural. A clear example of unidiomatic dialogue is then that which shows its agenda. When that happens, when whole iceberg (the straightjacket) can be seen, then the tip (the dialogue) becomes predictable, the viewer can see it coming. But what about idiomatic dialogue then?

Whereas for a given instance in spontaneous spoken language, we can expect to have several different idiomatic expressions (several nativelike [frequent] expressions, among the many possible ones in a given context), in prefabricated orality, there will be less nativelike (frequent) ones because there are less possible ones. This peculiarity of fictional dialogue closes the gap between what can be said and what is actually said, and therefore makes fictional dialogue, or at least idiomatic fictional dialogue, sound inevitable. Although invisible (and so not predictable), the iceberg has been built so well that it can only have one tip (or so it seems). Thus idiomatic fictional dialogue is not predictable, sounds necessary and seems inevitable.

Therefore, from this point of view, predictability would be the unidiomatic side of the coin and inevitability the idiomatic one. Hence the last two definitions: 
Fictional dialogue:

straightjacketed dialogue planned to be written been there, done that plot-driven object that is intended to sound natural and to eventually be acted as if not written passed off as a being there, doing that passed off as a plot-driving process

Unidiomatic fictional dialogue

straightjacketed dialogue that sounds unnatural and predictable.

Idiomatic fictional dialogue

straightjacketed dialogue that sounds natural and necessary and seems inevitable.

\subsection{The TT}

As mentioned at the beginning, the objective of the first part of this study was to outline those aspects that make dubbing dialogue different from real dialogue, mainly focusing on ST aspects. It goes without saying that TT-related aspects are also crucial in this regard, which is why, despite having taken a back seat here, they still deserve a brief mention.

With regard to AVT issues, scholars have traditionally turned their attention to the different constraints posed by this type of translation, particularly to synchronisation in the case of dubbing. Although it can possibly be seen as an attempt to help AVT establish itself as a discipline within Translation Studies, this approach has somehow fuelled the notion of AVT as a problem, rather than as a solution to a problem. The truth is, however, that the specificities of AVT are not restricted to the above-mentioned constraints. Previous research on this corpus, for instance, shows that AVT can sometimes provide the translator with considerable leeway to produce a natural TT (Romero Fresco 2007). In view of this, the theoretical model chosen for the qualitative analysis of the corpus under study is Frederic Chaume's model (2004a) for the analysis of audiovisual texts from a translational viewpoint, which offers an alternative to constraint-oriented approaches.

Chaume's model attempts to account for all the elements that produce the meaning of an audiovisual text, thus including both external factors (i.e., professional, historical, etc.) and other "general translation problems" (2004b:16) shared by all types of translation (linguistic, contextual, pragmatic, etc.). However, the main utility of Chaume's model for this paper lies in its emphasis on those factors that are particular to the audiovisual text and to AVT - the audiovisual codes of meaning. Like Delabastita (1989), Chaume regards the audiovisual text as a semiotic construct whose meaning, transmitted through the acoustic and the visual channels, is produced by the interaction of different codes. Every code is in turn made up of a number of signs that have a direct impact on the translator's task. Needless to say, the interaction of the audiovisual codes is crucial for the achievement of idiomaticity in the dubbed text: sometimes as an impediment, but always as a determining factor. Therefore, in this paper dubbing is not regarded only as a matter of (achieving) synchronisation, nor of (overcoming) constraints, but of (achieving) the satisfactory interaction of the different audiovisual codes. As mentioned above, special attention is given to the linguistic code due its relevance for the purpose of this study. 


\subsection{The prefabricated orality of the TT}

Regarding the linguistic code, the TT features a prefabricated orality that bears a great resemblance to that of the ST. The TT has also been planned to be written and to eventually be acted as if not written and attempts to sound natural while conforming to the conventions of fictional dialogue. However, there are differences between the prefabricated orality of the ST and that of the TT. Chaume (2004a:167 et seq.) offers a detailed account of a number of linguistic conventions that are specific to the Spanish dubbing language and that may be regarded as an obstacle to the achievement of an idiomatic dubbed text. For the sake of brevity, these conventions will not be included in this article, albeit they will be very much taken into consideration.

\section{Comparative analysis of dubbed and real dialogue}

Always bearing in mind the above determining factors that prevent dubbed dialogue from being completely natural, it is now time to turn to the second part of this article -a comparative analysis of real and dubbed dialogue. It is precisely at this point that the addition of the phrase in a given context to Warren's (2004:1) definition of naturalness ("nativelike selection of expression") comes into its own. As far as the mode is concerned, for instance, the TT features speech (oral mode) rather than writing, despite its undeniable written origin. The dubbing viewers do not read a script, they listen to supposedly spontaneous conversations. It thus follows that dubbing language is to be compared to spontaneous oral language and analyzed as such. This is a key distinction, as most studies on dubbese keep resorting to traditional "written tools" to describe it, even though what is natural in writing need not be natural in speech.

However, a comparison between dubbed dialogue and any spontaneous Spanish dialogue will not suffice either. The written-to-be-spoken-as-if-not-written contradiction of the dubbed text has often led to the consideration of orality as an essential element in the achievement of natural dubbed dialogues (Agost 1997). However, orality may not be a recipe for naturalness after all; at least not in dubbing. It may be in subtitling, where the written code the translator works on may be in need of certain oral features. In dubbing, however, there is no code-change, as both the ST and the TT feature speech. Thus, in the same way that what is natural in writing need not be natural in speech, what is natural in a formal conversation may not be natural in a colloquial one. This is the reason why naturalness rather than orality has been chosen as the key concept in this study and also why it is now necessary to further determine what context is being portrayed (or faked) in the TT.

\section{Register analysis}

Given the focus of this article, a good way to go about this is to establish what register and type of discourse is being used predominantly in the TT so that a comparison between the TT and a corpus of spontaneous Spanish conversation belonging to the same register can be drawn. In the case of Friends, the prevailing type of discourse is conversation and the predominant register is the colloquial register. Not all scenes in the TT can be classified as featuring colloquial conversation, but only scenes featuring colloquial conversation have been analyzed for this study. According to the 
parameters applied by Briz (1998) to the analysis of colloquial conversation, all the scenes analyzed here feature a type of discourse that is oral, dialogic, immediate, cooperative (with feedback), dynamic and with non-predetermined turn-taking. In turn, the register is unplanned, non-transactional (phatic, with interpersonal focus) and informal, and presents a relation of social and functional equality (-power +solidarity) and shared knowledge (proximity), with a familiar setting or interaction and a non-specialized theme.

The same holds true for most of the scenes in the Spanish sitcom included in this corpus, Siete vidas (SV), and certainly for all the scenes analyzed here. They provide a good opportunity to ascertain how natural non-translated fictional dialogue is as compared (polysystemically) to dubbed fictional dialogue. However, they cannot be used as a sample of spontaneous conversation, which is why the corpus CREA has also been used. Fortunately, CREA allows not only a distinction between written and oral sources, which would be sufficient if we were only striving for orality, but also further distinctions within oral sources between spontaneous and non-spontaneous conversations and finally between formal and colloquial spontaneous conversations. The latter constitute the yardstick to measure naturalness in this article and a valid term for comparison with both the TT and the Spanish sitcom.

\section{Searching for a model: units to be analyzed}

At this point, the initially vague concept of naturalness has been narrowed down considerably for its application to the analysis of the language used in dubbing, but there are still some important questions to be answered -what parameters can be used for this analysis? What are the units to be analyzed? Once again, it is the comparison between dubbing language and the language (or register) it is imitating that sheds light on this issue. If the dubbing language analyzed here is an imitation of Spanish colloquial conversation, then perhaps a number of recurrent patterns or characteristics of this register can be used as units to be comparatively analyzed in the TT, SV and CREA.

As a matter of fact, an ideal situation would be to find a model describing Spanish colloquial conversation thoroughly (its features, the strategies used, etc.), something like a grammar of colloquial conversation. Taking into account the above-mentioned distinctive features of dubbing language, the application of this model to a dubbed corpus could provide a very thorough characterization of dubbese from the point of view of its naturalness or lack thereof. Unfortunately, it seems that, at least with regard to the development of such a model, research on Spanish colloquial conversation has not come of age as yet. Most scholars are still addressing more specific issues like the study of the different parts involved in a conversation (Hidalgo Navarro 2003) or that of certain recurrent units such as discourse markers (Martín Zorraquino et al. 1998) or phraseology (Ruiz 1998).

For want of a descriptive model accounting thoroughly for colloquial conversation in Spanish, this article draws on the work carried out by Val.Es.Co., a corpusbased research group from Valencia investigating colloquial conversation. Antonio Briz, head of this group, outlines in his tentative pragmagrammar of colloquial conversation (1998) the main strategies used in Spanish colloquial conversation. Drawing on Tannen's (1984 and 1992) and Beaugrande and Dressler's (1981) functions of 
speech, these strategies are production, reception and connection (cohesion) strategies. Production and reception strategies are related to the speaker and the hearer respectively and regulate the social and interpersonal relationships among the participants. Connection (cohesion) strategies are related to the utterance and guarantee a cohesive and coherent interaction. These strategies are in turn associated with certain linguistic units, two of which (intensifiers and discourse markers) will be tackled in this article:

$\begin{array}{lll}\begin{array}{l}\text { production strategies - } \\ \text { reception strategies }-\end{array} & \begin{array}{l}\text { (related to) speaker - } \\ \text { (related to) hearer - }\end{array} & \begin{array}{l}\text { (associated with) intensifiers } \\ \text { (associated with) } \underline{\text { hedges }}\end{array} \\ \text { strategies - } & \text { (related to) utterance - } & \text { (associated with) discourse markers }\end{array}$

As will be explained in the corresponding sections below (8 and 9), the choice of intensifiers and discourse markers as objects of study is not only justified by their importance in real conversation but also by the key role they play in providing fictional dialogue, and especially dubbing dialogue, with naturalness. The case study included here consists of the analysis of the Spanish intensifiers en serio, de verdad and de veras, often as translations of the English intensifier really, and the discourse markers veamos, vamos a ver and a ver as translations of the recurrent English discourse marker let's see.

\section{The translation of intensifiers in dubbed and original sitcoms}

In the study of colloquial conversation, intensifiers are regarded both as a strategy and a pragmatic category that is related to the rhetoric activity of the speaker in relation to the hearer (Boyero 2002:128). They are linked to the notion of argumentative force and to Grice's cooperation maxims, especially quality and relevance of the speaker's contributions (Briz 1998:114). In fictional dialogue, intensifiers are often used to capture the attention of the audience. More importantly, in the particular case of Friends, they seem to contribute decisively to the naturalness of the dialogues, as demonstrated by Tagliamonte and Roberts (2005). Comparing the use of intensifiers such as really in the sitcom to two corpora of current English usage, the authors conclude that the language used in Friends "does reflect what is going on in language, at least with respect to the form, frequency, and patterning of intensifiers" (2005:299). The Spanish intensifiers analysed here (en serio, de verdad and de veras) are precisely the most common translations of really in the TT, where they are used to endorse asseverations and to stress the truth of an utterance as well as to assess and persuade. This study is thus an opportunity to find out whether the naturalness of the ST intensifiers is maintained in the TT.

In the parallel corpus used here, en serio, de verdad and de veras occur as translations of a considerably wide range of ST units. In a few cases, they are translations of apparently unrelated units such as $u h$ ? (2\%) or it's OK (4\%). More common is their occurrence as translations of the adverbs seriously/honestly (10\%) and of short answers made up by a personal pronoun and an auxiliary verb, such as it is, you do, we are, etc. (21\%). However, the most common ST unit triggering these TT intensifiers is by far the English adverb really (50\%): 
Rachel: No, you have it, really. I don't want it.

Rachel: No, de veras, no me apetece. $\quad$ (episode 1- season 1)

Interestingly enough, $69 \%$ of the cases in which really is translated as en serio/de verdad/de veras are questions:

Fireman 1: You're our third call tonight.

Rachel: Really?

Fireman 2: Oh, sure, Valentine's is our busiest night of the year.

Bombero 1: Es la tercera llamada de hoy.

Rachel: ¿En serio?

Bombero 2: Sí. San Valentín es la noche más atareada del año. (episode 14 - season 1)

Although on paper different from the previous example, the use of really/de verdad... in rhetoric questions is also regarded as a very common intensifying device in colloquial conversation (González Calvo 1987), usually endorsing the speaker's surprise or incredulity with regard to what has been said (Escandell 1993; Igualada 1994).

In any case, it may be worth reminding that the focus of the present study lies in the naturalness of the TT, not in that of the ST, which has been partly demonstrated by Tagliamonte and Roberts (2005) regarding the use of intensifiers. In other words, although the ST-TT comparison has been carried out, what really matters here is that between the TT, SV and CREA:

TABLE 3

Distribution of en serio, de verdad and de veras in TT, SV and CREA

\begin{tabular}{|l|l|l|l|}
\hline & Friends & Siete Vidas & $\begin{array}{l}\text { CREA } \\
\text { (coll. conversation) }\end{array}$ \\
\hline en serio & $58.6 \%$ & $53 \%$ & $61 \%$ \\
\hline de verdad & $15 \%$ & $47 \%$ & $39 \%$ \\
\hline de veras & $26.4 \%$ & $0 \%$ & $0 \%$ \\
\hline
\end{tabular}

Perhaps the most salient feature of the distribution of en serio/deverdad/de veras shown in Table 3 is the similarity between SV and CREA. Both feature en serio as the most common choice, followed by de verdad and showing no occurrence of de veras. In the TT in Friends, en serio is also the most recurrent intensifier (58.6\%), but in this case it is followed by de veras (26.4\%). How can de veras be so common (58 occurrences) in the dubbed translation and yet non-existent in the Spanish sitcom and the corpus of colloquial conversation?

The truth is that de veras does not sound very natural in colloquial conversation. However, the objective of this paper is to tackle naturalness empirically, so more evidence on the use of de veras in real life is needed in order to see whether or not this impressionistic view holds any water.

TABLE 4

en serio, de verdad and de veras in CREA - spontaneous conversations

\begin{tabular}{|l|l|l|}
\hline & Formal & Colloquial \\
\hline en serio & $0 \%$ & $100 \%$ \\
\hline de verdad & $23.7 \%$ & $76.3 \%$ \\
\hline de veras & $0 \%$ & $0 \%$ \\
\hline
\end{tabular}


Once again, although both en serio and de verdad are clearly more common in colloquial conversation (that is, more appropriate for a series like Friends), de veras does not occur in spontaneous conversation, whether formal or colloquial.

In fact, CREA features only six occurrences of de veras in speech. They are all recordings of TV magazines, none of which fulfils the criteria for colloquial conversation described above, given that turn-taking is predetermined and there is not always social and functional equality among the participants. As a matter of fact, in three of the six cases, de veras is uttered by politicians in rather formal interviews and another one is said by a writer who is reading out a poem by Lorca. Does this mean then that de veras is more common in writing than in speech?

TABLE 5

en serio, de verdad and de veras in CREA - written vs. oral

\begin{tabular}{|l|l|l|}
\hline & Written & Oral \\
\hline en serio & $59.9 \%$ & $40.1 \%$ \\
\hline de verdad & $43 \%$ & $57 \%$ \\
\hline de veras & $93.3 \%$ & $6.6 \%$ \\
\hline
\end{tabular}

As shown in Table 5, whereas en serio and de verdad are more or less equally distributed and thus appropriate for both speech and writing, in the case of de veras, the balance is clearly tipped in favour of writing. Although grammatically correct (possible), de veras is unusual, unnatural in (spontaneous) speech, and so unidiomatic when used in the dubbed version of Friends.

Moreover, a qualitative analysis of de veras in the TT shows that it is used in most cases $(71 \%)$ as a rhetoric question (to translate really?), much more often than en serio (43\%) and de verdad (9\%). In spontaneous colloquial conversation, however, it seems that not only ¿en serio? and ¿de verdad? are more natural questions than ¿de veras?, but also ¿ah, sí?, by far the most recurrent one in SV and CREA and yet still unusual in dubbing.

Before moving on to the analysis of discourse markers, a further distinction must be made that can perhaps shed some light on the reason why the apparently unusual de veras is being used in dubbing.

TABLE 6

en serio, de verdad and de veras in CREA (speech) - Latin American vs. Spain

\begin{tabular}{|l|l|l|}
\hline & Latin America & Spain \\
\hline en serio & $44 \%$ & $56 \%$ \\
\hline de verdad & $30.7 \%$ & $69.3 \%$ \\
\hline de veras & $85.5 \%$ & $14.5 \%$ \\
\hline
\end{tabular}

Table 6 shows a considerable difference in the oral use of the three intensifiers in Spain and Latin America. Both en serio and, to a greater extent, de verdad are more frequent in Spain, but it is de veras that shows the biggest difference, being considerably much more common in Latin American speech. This is a key fact given that, when films were first dubbed from English into Spanish in the early 60s, only one Spanish version was produced for the whole Spanish-speaking audience in Spain and Latin America. This version featured a standardized form of Spanish (the so-called 
español neutro) and was not dubbed in Spain, but in Mexico, Puerto Rico and Florida, mostly by Latin American professionals. Since 1975, films are dubbed twice, once in Spain for its audience and once in Latin America, but perhaps the use of de veras, unidiomatic in Spain but natural in Latin America, is a vestige of the old español neutro used in the $60 \mathrm{~s}^{4}$. Moreover, in order to be understood by very different Spanish-speaking audiences, this español neutro was devoid of dialectal features and is thus usually regarded as stilted, contrived and even too formal (Petrella 1998). Although more research needs to be done to confirm this, the rise and inconsistency in tenor sometimes found in dubbed films, and certainly in previous studies on idioms with this corpus (Romero Fresco 2005), could well be due to the influence of this old español neutro and its combination with more modern choices. In any case and whatever the cause, the use of de veras in the TT, produced for Spain, remains unnatural and unidiomatic.

\section{The translation of discourse markers in dubbed and original sitcoms}

Described by Pons (2005:28) as "a melting pot of problems and perspectives" and often subject to very different definitions and classifications, the study of discourse markers only seems to elicit consensus as to their enormous importance in the construction of coherent conversation. Schiffrin (1987:31) describes them as "as sequentially dependent elements which bracket units of talk," the vagueness of her description being due to the very different nature of the units bracketed and the difficulty to classify markers using the traditional grammatical categories. According to Schiffrin (1987:328), the main characteristics of discourse markers are that they are syntactically detachable from a sentence, they are commonly used in initial position of an utterance, they have a range of prosodic contours (i.e., tonic stress and followed by a pause), they operate at local and global levels of discourse and they have either no meaning or vague, diminished meaning. Besides, Schiffrin (1987:327) considers discourse markers at a more theoretical level as contextual coordinates that are essential to regulate conversation, make clear the speaker's intentions and produce a coherent discourse.

Looking precisely at discourse markers from a translational viewpoint, Chaume (2004c:844) points out that translators must try to understand their pragmatic meaning in order to "produce the same effect on the addressees of the target text as the source text produced on its own addressees" and convey the author's intentions. Interesting as it is, Chaume's study focuses on a comparative analysis of ST and TT, whereas the objective here is to comparatively analyze not only ST (mainly let's see) and TT (a ver, vamos a ver and veamos) discourse markers, but also the use of the latter in fake (SV) and real (CREA) Spanish conversation in order to assess the (un)naturalness of the dubbed translation.

Briz (1998:201) regards these markers as metadiscourse markers. They are signs of the effort made by the speakers to formulate and re-formulate their discourse as they speak, a quick plan to face the on-line production of the discourse and solve possible communication problems (Briz 1998:202). Thus, unlike, for instance, argumentative markers (por lo tanto >therefore, en suma $>$ in sum), which are frequent in both speech and writing, metadiscourse markers are more common in speech, especially in colloquial conversation. They allow colloquial conversation to work, and are therefore particularly relevant to the description of dubbing language as an imitation of 
this register. As a matter of fact, the use of this kind of conversational discourse markers is consistently regarded as a common device used by scriptwriters to provide their dialogues with real-life naturalness (Vanoye 1985, Kobus 1998). The same holds true for dubbing, where style sheets recommend translators to use precisely some of the metadiscourse markers analysed in this study to produce spontaneous-sounding dialogues (Televisió de Catalunya 1997).

Therefore, let's see - vamos a ver, a ver and veamos are not regarded here as imperatives or commands, but as markers used by the speaker to make a brief pause in the discourse without losing the floor, thus gaining some time to think and make the hearer focus on the upcoming information:

Joey: So, when do we get to meet the guy?

Monica: Let's see, today's Monday... Never.

Joey: Y cuando vamos a conocerle?

Monica: Veamos, hoy es lunes...Nunca. $\quad$ (episode 3 - season 1)

TABLE 7

Distribution of $a$ ver, vamos a ver and veamos in TT, SV and CREA

\begin{tabular}{|l|l|l|l|}
\hline & Friends & Siete Vidas & CREA (coll. conv.) \\
\hline a ver & $37.8 \%$ & $67.9 \%$ & $77.7 . \%$ \\
\hline vamos a ver & $17.8 \%$ & $32.1 \%$ & $22.3 \%$ \\
\hline veamos & $44.4 \%$ & $0 \%$ & $0 \%$ \\
\hline
\end{tabular}

Table 7 shows the distribution of the three Spanish markers in the dubbed sitcom, the original sitcom (SV) and the colloquial section of the speech corpus (CREA). Once again, SV seems to mirror CREA, a ver being the most common one, followed by vamos a ver. In the dubbed version of Friends, however, although a ver is also quite common (37.8\%), the most recurrent choice is veamos (44.4.\%), which does not feature in SV or CREA. Why is then veamos so frequent in the TT? Could it be due to the influence of the ST?

TABLE 8

Occurrences of let's see and veamos

\begin{tabular}{|l|l|l|l|}
\hline ST & TT & ST & TT \\
\hline Let'see & veamos & & \\
Let'see & ----- & Ok & \\
Let'see & vamos a ver & Ok & veamos \\
Let'see & veamos & Ok, all right & veamos \\
Let'see & veamos & Ok & veamos \\
Let'see & muy bien & So.. & veamos \\
Let'see & ---- & Alright & veamos \\
Let'see & veamos & Well, for instance & veamos \\
Let'see & veamos & Well, ah & veamos \\
Let'see & ---- & Now & veamos \\
Let'see & veamos & Ok & veamos \\
Let'see & veamos & & \\
Let'see & veamos & & \\
Let'see & veamos & & \\
Let'see & veamos & & \\
\hline
\end{tabular}


As shown in Table 8, 10 of the 15 occurrences of let's see in the ST are translated as veamos, which is a literal translation and could probably be considered as an Anglicism of frequency (Vázquez Ayora 1977:102-140; Lorenzo 1996:91-92): it exists in Spanish, but it does not seem to be as frequent as let's see or as a ver and vamos a ver. But what is really interesting here is that the other 10 occurrences of veamos are not motivated by let's see. They are translations of $O K$, all right, so, well and now, very different units that fulfil, however, the same pragmatic role as (meta)discourse markers used by the speakers to buy some time before their utterance. Finally, a qualitative analysis of these markers shows another tendency: veamos seems to be motivated by let's see in the first episodes and by the other markers in subsequent episodes. What does this mean? Can veamos be considered as a calque from let's see if it is also being triggered by other ST units? In order to answer these questions, it is essential to consider first the role played by veamos in real speech.

TABLE 9

a ver, vamos a ver and veamos in CREA: spontaneous conversation

\begin{tabular}{|l|l|l|}
\hline & Formal & Colloquial \\
\hline a ver & $0.3 \%$ & $99.7 \%$ \\
\hline vamos a ver & $20 \%$ & $80 \%$ \\
\hline Veamos & $0 \%$ & $0 \%$ \\
\hline
\end{tabular}

Both vamos a ver and, to a greater extent, a ver seem more appropriate for colloquial than formal spontaneous conversation. Veamos does not occur in this situation.

TABLE 10

a ver, vamos a ver and veamos in CREA: written vs. oral

\begin{tabular}{|l|l|l|}
\hline & Written & Oral \\
\hline a ver & $13.7 \%$ & $86.3 \%$ \\
\hline vamos a ver & $7.1 \%$ & $92.9 \%$ \\
\hline veamos & $88.4 \%$ & $11.6 \%$ \\
\hline
\end{tabular}

As far as the written-oral distinction is concerned, a ver and vamos a ver are significantly more recurrent in speech than in writing, whereas veamos mostly occurs in writing (88.4\%). However, this is not to say that veamos cannot be used in speech. In fact, up to 11 oral uses of veamos have been found in CREA, all of which are uttered by teachers or journalists in classes and TV programmes. In 3 cases, veamos is used literally as an imperative, the teacher/journalist telling the students/audience to see something. The other 8 cases are oral uses of veamos as a (meta)discourse marker, but the situations cannot be described as presenting colloquial conversation: turntaking is predetermined, the discourse is more or less planned and there is not social and functional equality (+power, -solidarity). ${ }^{5}$

To summarize, veamos is first and foremost used in writing. It can sometimes be found in speech, but it is not natural when used in colloquial conversation, just like it is used in the dubbed version of Friends. For this situation, both vamos a ver and especially a ver are much more idiomatic. 


\section{Conclusion}

This article is intended as a contribution to develop the understudied and yet very important (at least within AVT) area of dubbing language, whose main, though not only, interest lies in the contradiction between its written origin and its oral purpose. Given that dubbing language has traditionally been described as stilted and contrived, it has been analyzed here precisely from the point of view of its (un)naturalness. One of the main objectives was to find an empirically valid way to assess naturalness, thus avoiding the still common impressionistic statements on the issue. Partly drawing on Warren (2004), naturalness is regarded in this article not as what is possible, but as what is frequent among different possible choices. The definition of naturalness adopted here is nativelike selection of expression in a given context. Taking into consideration this context or situation, dubbing language, in this case the Spanish dubbing language, has been considered as a particular type of colloquial conversation: an imitation of colloquial conversation with special features.

First of all, these particularities or special features have been tackled, showing that fictional dialogue is actually more elaborated than it is usually believed (planned to be written and to eventually be acted as if not written). Stressing the importance of the planning and elaboration of the ST in its naturalness and in that of the TT, three definitions of fictional dialogue have been put forward: straightjacketed dialogue that is intended to sound natural, a "been there, done that" passed off as a "being there, doing that" and a plot-driven object passed off as a plot-driving process. Likewise, unidiomatic (straightjacketed dialogue that sounds unnatural and predictable) and idiomatic fictional dialogue (straightjacketed dialogue that sounds natural and necessary and seems inevitable) have also been defined.

Once the particularities of fictional dialogue and those of AVT have been considered, dubbing dialogue has been compared to real dialogue and, more specifically, to colloquial conversation. A set of criteria defining colloquial conversation has also been put forward, criteria that are fulfilled by all the corpora under study: the original and dubbed versions of Friends, the Spanish sitcom (SV) and the real speech corpus (CREA). The latter has been used as a yardstick to assess the naturalness of the dubbed dialogue. Besides, this comparison between dubbed dialogue and colloquial conversation has proved to be very useful, providing a number of units that can be used as parameters to assess the naturalness of the language used in dubbing. Only a sample of the key pragmatic categories of intensifiers and discourse markers has been analyzed here, but the increasingly rich literature on colloquial conversation guarantees a promising feature for the study of dubbing language from this perspective.

The analysis of these intensifiers and discourse markers shows that there is a clear similarity between SV and CREA, whereas this is not always the case with the dubbed script. With regard to the intensifiers en serio, de verdad and de veras, mainly as translations of really, both en serio and de verdad have proved to be natural in Spanish colloquial conversation and commonly used in the TT and SV. De veras presents a different situation. It is strikingly common in the dubbed script but it does not feature in SV or in the colloquial section of CREA. In fact, it is only common in the written section of CREA, which indicates that it is more idiomatic in writing and usually in more formal contexts. Therefore, the use of de veras to translate really in dubbed conversations, especially as a rhetoric question (¿de veras?) is unnatural and 
could be replaced by more idiomatic alternatives such as ¿en serio?, ¿de verdad? and the very natural and yet often forgotten $\dot{¿} a h$, sí?

The (meta)discourse markers a ver, vamos a ver and veamos, mainly as translations of let's see, show a similar pattern -similarity between SV and CREA, idiomatic use of $a$ ver and vamos a ver in the TT and unusually high occurrence in the TT of a not very natural marker, veamos. The difference, in this case, is that veamos can be (and actually is) used in speech. As a discourse marker, as opposed to as an imperative, it is often used by teachers and TV presenters to address students and audiences. However, although oral, this situation is far from being colloquial: the discourse is planned to some extent and the relationship between the participants uneven (+power, - solidarity). Thus, orality does not suffice to make dubbing dialogue idiomatic. It has to be the right type of orality, in this case colloquial conversation. It is for this reason that naturalness/idiomaticity rather than orality has been chosen as the mainstay of this study.

In any case, veamos, the most favoured choice in the dubbed script, is unnatural in colloquial conversation, and probably a calque of let's see. Just as happens with de veras, veamos is possible (it is grammatically correct and has the same meaning as the ST unit it translates), but it is not idiomatic in the particular situation in which it is used. Besides, the use of these units introduces a new and distinctive feature - in an otherwise familiar setting and friendly atmosphere, a given character suddenly addresses his/her friends as if he/she was teaching them or even reading a book. A new relationship of more power and less solidarity is thus introduced, TT characters suddenly becoming not-so-close friends. Needless to say, this distance was not present in the ST and is bound to produce a different effect on the addressees of the TT. Although it is still too soon to draw conclusions on the nature and effect of dubbese, it seems to provide the TT with a certain foreign flavour and a formal tone that ultimately sound unnatural.

\section{Final words on the origin of unnatural dubbese: the suspension of linguistic disbelief}

Having found a series of unnatural features in the use of intensifiers and discourse markers in dubbese, there are still a couple of questions to be addressed: can veamos be considered as a calque from let's see if it is also being triggered by other ST units? Can de veras be explained simply as a vestige of the old español neutro? And, more generally, where does this unidiomatic nature of dubbese come from?

The fact that we are dealing with fictional dialogue cannot be put down as a reason for this lack of naturalness. Both the ST and SV feature fictional dialogue and yet none of them has these unnatural features, as proved by Tagliamonte and Roberts (2005) in the case of the ST and by the similarity between SV and CREA in the case of the Spanish sitcom. AVT issues cannot account for this lack of naturalness either. The application of Chaume's model in the qualitative analysis of the TT shows that more than $90 \%$ of the scenes under study allowed a more natural translation. In terms of lip synchrony, for example, the use of the unidiomatic ¿de veras? to translate really? adds an unnecessary bilabial, thus being less "synchrony-friendly" than ¿en serio? or ¿ah, si?

Not even the prefabricated orality of the TT can explain the unidiomatic nature of dubbese in this case. In Spain, dubbing translators are advised to use a colloquial 
register in their translations, but with certain restrictions, so that the audience can follow the plot without much problem (Chaume 2004a:169). Hesitations, hyperbatons and anacoluthons are not to be used, and neither are non-grammatical constructions or relaxed pronunciations. However, as pointed out by Chaume (2004a:179), translators are encouraged to highlight the colloquial nature of their translations by resorting to (colloquial) discourse markers and intensifiers. Therefore, the unidiomatic use of ¿de veras? and veamos cannot be explained by this set of conventions/restrictions either.

As explained elsewhere (Romero Fresco 2008), a possible answer to this question may lie in how dubbing is accepted in the first place by the audience; in other words, how the audience manages to suspend disbelief when watching a dubbed film. Palencia Villa (2002) uses two concepts that are essential to understand this phenomenon: the wish to enjoy the diegetic experience and the genre effect. As for the first one, Palencia Villa explains that the conventions at play in dubbing (synchrony, credibility of the dialogues, coherence between what is heard and what is seen, etc.) are often subordinated to the wish on the part of the audience to enjoy the diegetic experience of "entering" a film. Most importantly, Palencia Villa adds that these dubbing conventions accepted in tacit agreement are actually accepted as part and parcel of watching a film. In other words, in the same way that ST viewers do not question why a voice coming from a distant character walking off into the horizon is heard as though s/he was sitting beside them, the TT viewers do not question why this character speaks Spanish in what seems to be an English-speaking environment. The obstacles posed by the dubbing conventions thus become one more cinematic convention that is surpassed thanks to the wish to enjoy the cinematic experience. Furthermore, this is facilitated by the second element mentioned by Palencia Villa, the genre-effect, i.e., the effect caused by the repeated viewing of different products/ texts belonging to the same genre, in this case different dramatic audiovisual texts. In this way, by watching dubbed films or sitcoms, the TT viewers learn the dubbing conventions, get used to them and avoid questioning them in order to enjoy the viewing.

The wish to enjoy the diegetic experience and the genre effect thus explain how the dubbing audience manages to suspend disbelief and crucially point towards an answer for the question of why unnatural features appear in the TT. Indeed, it could be argued that, ready as they are to suspend disbelief with regard to cinematic and dubbing conventions, the TT viewers are also likely to end up suspending disbelief with regard to the lack of naturalness of the TT. In the same way that they do not question the clear sound of a distant voice (cinematic convention) or the fact that Rachel speaks Spanish in New York (dubbing convention), they may also not question that the Spanish used by Rachel is not necessarily the Spanish they would use in that situation. In other words, they suspend linguistic disbelief, thus accepting the use of ¿de veras? as one more cinematic convention to be overlooked in order to enjoy the cinematic experience. Indeed, as put by Chion (1993), when hearing the supposedly realistic sound of a dubbed film, viewers are not in a position to compare it to the real sound that would be heard in a similar real-life situation. Instead, they compare it to their memory of that sound, which is in turn influenced by the viewing of other dubbed films that may contain unnatural dialogue. The suspension of linguistic disbelief can thus be defined as the process that allows the dubbing audience to turn a 
deaf ear to the possible unnaturalness of the dubbed script while enjoying the cinematic experience.

The key point here for the question tackled in this discussion is that, as TT viewers, dubbing translators are also very likely to end up suspending linguistic disbelief, which may explain why there is still lack of naturalness in the Spanish dubbing language. If the translator of Friends was comparing his/her dubbed text to real speech, to real colloquial conversation, s/he would probably not use ¿de veras? as an intensifier, given that it is hardly ever used among friends. However, if $s /$ he is suspending linguistic disbelief, s/he is not comparing his/her dubbed script to real dialogue, but to other dubbed films or sitcoms that may contain ¿de veras? in this situation. The use of veamos can also be explained in this way. The translator starts using veamos, a calque of let's see, in the first episodes as a (meta)discourse marker, in situations in which the speaker needs to buy time to think before an utterance. By using it, veamos becomes part of the translator's dubbing language, of the dubbese that $s /$ he is going to use to translate Friends. In subsequent episodes and seasons, when this situation arises again (and it does, given the above-mentioned formulaic nature of sitcoms), the translator uses veamos again, even if it is not motivated by let's see but by other ST units such as OK or well. The suspension of linguistic disbelief is thus not so much responsible for the introduction of unnatural features in dubbing language (a question that needs to be researched), but for their perpetuation. Following from this, it would appear that, due to the nature of this phenomenon, the more recurrent unnatural features are in dubbing, the more likely they are to be overlooked by the viewers, who get used to them, and perhaps by translators too. In this sense, the fact that Friends has been broadcast daily for the past ten years on Spanish TV is very likely to have played an important role in the consolidation of the above-mentioned unnatural DMs as a common occurrence in the Spanish dubbing language.

To conclude, it has been said that, since their childhood (Whitman-Linsen 1991) viewers learn not to question cinematic conventions such as when they are able to hear conversations whose participants are still not shown on the screen. It is by watching this type of scene and accepting the conditions established by cinematic conventions that viewers develop their relationship with cinema, thus learning how to enjoy the cinematic experience. In the case of dubbing, this relationship is more demanding, as it has a further set of conditions: the dubbing conventions. However, this does not seem to be a problem, given that TT viewers readily accept them as if they were a new group of cinematic codes, that is, as if they were part and parcel of watching a film. The problem is that, by suspending linguistic disbelief, the dubbing audience may also be accepting a condition, the lack of naturalness of dubbed dialogues, that does not necessarily have to be part of the filmic experience and that, most importantly, may change or even impoverish this experience (for instance, by turning colloquial dialogue into formal dialogue, thus creating a considerable distance between TT characters). The analysis included in this thesis suggests that this lack of naturalness may be overcome, as it is not caused by dubbing constraints. It also indicates that a more thorough comparison with spontaneous conversation on the part of dubbing translators, should they have the time and/or inclination to do so, may be a good way to avoid the suspension of linguistic disbelief, which seems to perpetuate this problem. 
In any case, though, a much more thorough description of dubbese is needed in order to draw conclusions on this key question of naturalness in dubbing as well as on the exact role played by the suspension of linguistic disbelief in this issue.

\section{NOTES}

1. This article has been written in the framework of the research project "La subtitulación para sordos y la audiodescripción: primeras aproximaciones científicas y su aplicación” (HUM2006-03653FILO), funded by the Spanish Ministry of Education.

2. This article is drawn from a Ph.D. thesis undertaken by the author at Heriot-Watt University (Edinburgh).

3. Given that, as will be described in 4.3., the audiovisual text is regarded here as a semiotic construct comprising several signifying codes (shooting code, sound code, paralinguistic code, etc.). (Chaume 2004), its naturalness cannot be assessed only on the basis of the linguistic code. However, this is the only code the translator can usually alter, which is why it has been chosen as the focus of this article.

4. As a matter of fact, this español neutro is still used nowadays as the only version in Spanish for all Spanish-speaking Latin American countries (Castro Roig 1996); not only to translate films, but also software and multimedia products in general.

5. The Latin America-Spain distinction has not proved to be relevant in this case. Veamos is more recurrent in Latin American speech than in that from Spain, but most of these uses (92\%) correspond to formal speeches (Parliament, etc.), not to colloquial conversation, in which it is very unusual.

\section{REFERENCES}

Agost, R. (1997): “La traducció per al doblatge: a la recerca de l'equilibri entre oralitat I escriptura," Quaderns de Filologia. Estudis lingüistics. Sobre l'oral i l'escrit, pp. 109-124.

BAKhtin, M. M. (1986): Speech genres and other late essays, in Emerson, C. and M. Holquist (eds.), Austin, University of Texas Press.

Baumgarten, N. (2005): The Secret Agent: Film dubbing and the influence of the English language on German communicative preferences. Towards a model for the analysis of language use in visual media, Ph.D. Thesis, University of Hamburg.

Beaugrande, R. A. and W. U. Dressler (1981): Introduction to text linguistics, London/New York, Longman.

Berger, A. A. (1990): Scripts. Writing for Radio and Television, Newbury Park, London/New Delhi, Sage Publications.

Boyero Rodríguez, M. J. (2002): Los marcadores conversacionales que intervienen en el desarrollo del diálogo, Salamanca, Publicaciones Universidad Pontificia de Salamanca.

Boxer, D. (2002): Applying sociolinguistics: Domains of face-to-face interaction, Amsterdam, Benjamins.

Bravo, J. M. (2005): "La investigación en traducción cinematográfica en España: el doblaje (inglés-español)," in Merino Álvarez, R., Santamaría, J. M. and E. Pajares (eds.), Trasvases culturales 4: literatura, cine, traducción, País Vasco, Universidad del País Vasco, pp. 123-144.

Briz Gómez, A. (1998): El español coloquial en la conversación, Barcelona, Ariel.

Castro Roig, X. (1996): “El español neutro," Annual ATA Conference, Colorado Springs, USA, $<$ http://xcastro.com/neutro.html> (accessed October 15 $5^{\text {th }}, 2008$ ).

Chaume, F. (2004a): Cine y traducción, Madrid, Cátedra.

Chaume, F. (2004b): "Film Studies and Translation Studies: Two Disciplines at Stake in Audiovisual Translation," Meta 49-1, pp. 12-24.

Chaume, F. (2004c): “Discourse Markers in Audiovisual Translating," Meta 49-4, pp. 843-855.

Chaume, F. (2007): "Quality standards in dubbing: a proposal," TradTerm 13, pp. 71-89.

Chiaro, D. (2005): "Suspension of disbelief or mediatic diglossia? How Italians perceive Dubbese," in MuTra 2005 Challenges of Multidimensional Translation, Saarbrücken (May 2-6, 
2005), <http://www.euroconferences.info/2005_abstracts.php> (accessed October $15^{\text {th }}$, 2008).

Chion, M. (1982/1993): La audiovisión. Introducción a un análisis conjunto de la imagen y el Sonido, Barcelona, Paidós.

Delabastita, D. (1989): "Translation and mass-communication: film and T.V. translation as evidence of cultural dynamics," Babel 35-4, pp. 193-218.

Duro Moreno, M. (2001): “Eres patético': el español traducido del cine y de la Televisión,” in Duro Moreno, M. (ed.), La traducción para el doblaje y la subtitulación, Madrid, Cátedra, pp. 161-185.

EsCANDELL, M. V. (1993): Introducción a la pragmática, Barcelona, Anthropos.

Gambier, Y. (2006): "Multimodality and Audiovisual Translation," MuTra conference Audiovisual Translation Scenarios, Copenhagen (May 1-5, 2006), <http://www.euroconferences. info/2006_abstracts.php\#Gambier> (accessed October 15 ${ }^{\text {th }}$ 2008).

Gómez Capuz, J. (2001): "Diseño de análisis de la interferencia pragmática en la traducción audiovisual del inglés al español," in SAnderson, J. D. (ed.), Doble o nada. Actas de las I y II Jornadas de doblaje y subtitulación, Alicante, Universidad de Alicante, pp. 59-84.

GonzÁlez Calvo, J. M. (1987): “Sobre la expression de lo 'superlativo' en español,” Anuario de Estudios Filológicos 10, pp. 101-132.

Gregory, M. and S. Carroll (1978): Language and Situation: Language Varieties and their Social Contexts, London, Routledge.

Halliday, M.A.K. (1985): Spoken and Written Language, Victoria, Deakin University.

HeIss, C. (2004): “Dubbing Multilingual Films: A New Challenge?," Meta 49-1, pp. 208-220.

Herbst, T. (1994): Linguistische Aspekte der Synchronisation von Fernsehserien, Tübingen/Niemeyer, Linguistische Arbeiten 318.

Hidalgo Navarro, A. (2003): "Microestructura discursiva y segmentación informativa en la conversación coloquial," ELUA 17, Alicante, Universidad de Alicante, pp. 367-386.

Huerta, M. A. (2005): “Las sitcom en televisión. La verdad, el dolor y la risa inteligente," Revista Universitaria de la Pontificia Universidad Católica de Chile 89, pp. 14-18.

Igualada, M. (1994): "Estrategias comunicativas. La pregunta retórica en español," R.S.E.L. 24-2, pp. 329-344.

Kelly, R. (2003): “How a US Sitcom is Made," Writing for Performance, <http://www.robinkelly. btinternet.co.uk/ussitcom.htm>, (accessed October $15^{\text {th }} 2008$ ).

Kobus, I. (1998): Dialog in Roman und Film: Untersuchungen zu Joseph Loseys Literaturverfilmungen The Go-Between und Accident, Frankfurt, Peter Lang.

Lorenzo, E. (1996): Anglicismos hispánicos, Madrid, Gredos.

Martín Zorraquino, Ma . A. and E. Montolío Durán (eds.) (1998): Los marcadores del discurso. Teoría y análisis, Madrid, Arco Libros.

Marzì, A., Chaume, F., Torralba, G. and A. Alemany (2006): "The language we watch: an approach to the linguistic model of Catalan in dubbing," Jones, G. (ed.), Mercator Media Forum 9.

Mayhew Archer, P. (2005): "Interview for Sitcom Workshop," Writing for Performance, $<$ http://www.robinkelly.btinternet.co.uk/c41.htm > (accessed October $15^{\text {th }} 2008$ ).

Murphy, R. P. (1977): “The feature film and sociolinguistics," Forum Linguisticum 2, pp. 171176.

Myers, L. (1973): “The Art of Dubbing," Filmmakers Newsletter 6, pp. 56-58.

Nye, S., Barron, F. and M. ЈАСОв (2005): "Writing comedy," in Get Writing, <http://www.bbc. co.uk/dna/getwriting/module28p $>$ (accessed October 15 $5^{\text {th }}, 2008$ ).

Onions, C. T. (ed.) (1964): The Shorter Oxford English Dictionary, Oxford, Clarendon.

Palencia Villa, R. M. (2002): La influencia del doblaje audiovisual en la percepción de los personajes, Ph.D. Thesis, Universidad Autónoma de Barcelona.

Pavesi, M. and E. Perego (2006): "Profiling Film Translators in Italy: A Preliminary Analysis," The Journal of Specialised Translation 6, <http://www.jostrans.org/issue06/art_pavesi.php> (accessed October $15^{\text {th }} 2008$ ). 
Pawley, A. and F. Syder (1983): "Two puzzles for linguistic theory: nativelike selection and nativelike fluency," in Richards, J. C. and W. Schmidt (eds.), Language and Communication 7-1, London, Longman, pp. 191-226.

Pérez Gonzalez, L. (2007): “Appraising Dubbed Conversation. Systemic Functional Insights into the Construal of Naturalness in Translated Film Dialogue," The Translator 13-1, pp. 1-38.

Petrella, L. (1998): “El español 'neutro' de los doblajes: intenciones y realidades en Hispanoamérica," in Cortés BARgalló, L., GARCíA-TORT, C. \& C. MAPA (eds.), La lengua española y los medios de comunicación, tomo II, Mexico City, SEP \& Instituto Cervantes, pp. 977-988.

Pfister, M. (2001): Das Drama, Munich, Wilhelm Fink Verlag (UTB).

Pons, S. (2005): "A Functional Approach for the Study of Discourse Markers," in Fischer, K. (ed.), Approaches to Discourse Particles, Amsterdam, John Benjamins, <http://people.bu. edu/bfraser/Pragmatically\%20Oriented/Pons\%20-\%202005\%20-\%20A\%20Functional\%20 Appr.\%20for\%20DMs.doc >.

Pratt, M. L. (1977): Towards a Speech Act Theory of Literary Discourse, Bloomington, Indiana University Press.

Remael, A. (2003): “Mainstream Narrative Film Dialogue and Subtitling," The Translator 9-2, pp. 225-247.

Romero Fresco, P. (2005): “The translation of phraseology in a parallel audiovisual Corpus," Corpus Linguistics Conference Series 1-1, <www.corpus.bham.ac.uk/PCLC> (accessed October $\left.15^{\text {th }} 2008\right)$.

Romero Fresco, P. (2007): "Synching and swimming naturally on the side - the translation of hesitation in dubbing," Linguistica Antverpiensia NS6, pp. 185-202.

Romero Fresco, P. (2008): A corpus-based study on the naturalness of the Spanish dubbing language, Unpublished $\mathrm{PhD}$ thesis, Heriot-Watt University.

Rose, K. R. (2001): "Compliments and compliment responses in film: Implications for pragmatics research and language teaching," International Review of Applied Linguistics 39, pp. 309326.

Ruiz, L. (1998): La fraseología del español coloquial, Barcelona, Ariel.

Schiffrin, D. (1987): Discourse Markers, Cambridge, Cambridge University Press.

Sinclair, J. (ed.) (1995): Collins Cobuild English Dictionary, Glasgow, HarperCollins Publishers.

Tagliamonte, S. and C. Roberts (2005): "So weird; so cool; so innovative: the use of intensifiers in the television series Friends," American Speech 8-3, pp. 280-300.

Tannen, D. (ed.) (1984): Conversational Style: Analyzing Talk Among Friends, Norwood, Ablex.

TANnen, D. (1992): Talking Voices. Repetition, Dialogue and Imagery in Conversational Discourse, Cambridge, Cambridge University Press.

Tannen, D. and R. Lakoff (1994): "Conversational strategy and metastrategy in a pragmatic theory: The example of scenes from a marriage," in TANnEN, D. (ed.), Gender and Discourse, Oxford, Oxford University Press, pp. 137-173.

Televisió de Catalunya (1997): Criteris Lingüístics sobre Traducció i Doblatge, Barcelona, Edicions 62.

VÁzquez Ayora, G. (1977): Introducción a la traductología, Washington, Georgetown University Press.

VANoye, F. (1985): «Conversations publiques», in VANOYe, F. (dir.), La parole au cinéma/Speech in Film, numéro spécial Iris 3-1, pp. 99-118.

Walter, E. (2005): Cambridge Advanced Learner's Dictionary, Cambridge, Cambridge University Press.

Warren, B. (2004): "A model of idiomaticity," paper presented at the Ninth Nordic Conference

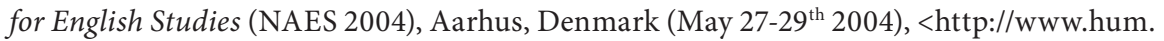
au.dk/engelsk/naes2004/download_paper.html?ID=1>.

Whitman-Linsen, C. (1991): Through the Dubbing Glass. The Synchronization of American Pictures into German, French and Spanish, Frankfurt, Peter Lang. 